\title{
Ikhlas Kontraktual dan Ikhlas Non Kontraktual: Kontekstualisasi Motto Ikhlas Beramal di Era Human Capital 9
}

\author{
Dian Hafit Syaifullah | Budi Permana Yusuf | Sunarta
}

How to cite : Syaifullah, D., H., \& Yusuf, B., P.,.(2020). Ikhlas Kontraktual dan Ikhlas Non Kontraktual: Kontekstualisasi Motto Ikhlas Beramal di Era Human Capital 9. 1(1). Jurnal Jurnal Manajemen Bisnis dan Publik(JMBP). 41-47.

To link to this article : https://doi.org/10.22236/jmbp.v1i1.5687

Opened Access Article

Published Online on 12 November 2020

Submit your paper to this journal 
Recieved: 09 Oktober 2020 Accepted: 1 November 2020 Published: 12 November 2020

${ }^{*}$ Corresponding author: Dian Hafit Syaifullah, Universitas Muhammadiyah Prof Dr Hamka, Indonesia

E-mail:

dianhafitsyaifullah@gmail.com

Reviewing editor:

Bambang Dwi Hartono, Universitas Muhammadiyah Prof. DR. HAMKA- Jakarta.

Additional information is available at the end of the article

\section{Ikhlas Kontraktual dan Ikhlas Non Kontraktual: Kontekstualisasi Motto Ikhlas Beramal di Era Human Capital 9}

\author{
Dian Hafit Syaifullah, Budi Permana Yusuf, Sunarta
}

Abstrak. Ikhlas beramal merupakan motto Kementerian Agama yang belum pernah didefinisikan secara institusional oleh Kementerian Agama sejak awal kelahirannya. Artikel ini bertujuan untuk mengidentifikasi nilai-nilai organizational citizenship behavior dan employee engagement mana saja yang yang bersesuaian dengan makna ikhlas beramal. Artikel ini menggunakan pendekatan kualitatif dengan teknik literature study, pengumpulan data dilakukan melalui Teknik stock taking dengan cara mengumpulkan dan mengklasifikasi berbagai textbook dan jurnal serta berbagai penelitian terdahulu yang relevan. Kajian ini menemukan bahwa organizational citizenship behavior dapat dipadankan dengan ikhlas non kontraktual dan employee engagement dapat dipadankan dengan ikhlas kontraktual karena memiliki nilai-nilai tertentu yang bersesuaian dengan beberapa nilai keikhlasan. Diperlukan berbagai kajian lanjutan untuk menguji temuan ini.

Kata Kunci : ikhlas contractual; ikhlas non kontraktual; public services; motto Kementerian Agama.

\section{TENTANG PENULIS}

Dian Hafit Syaifullah adalah adalah mahasiswa pascasarjana UHAMKA yang lulus pada tahun 2020. la saat ini sedang aktif dalam penelitian-penelitian yang terkait dengan branding suatu produk dalam memasuki pasar nasional dan internasional.

\section{Bambang Pernama Yusuf adalah Dosen Sekolah Pascasarjana Universitas Muhammadiyah Prof. DR. HAMKA pada program studi Magister Manajemen. la saat ini sedang aktif dalam berbagai penelitian terkait dengan manajemen dan bisnis pada kebijakan publik.}

\section{PENELITIAN SEBELUMNYA}

Penelitian sebelumnya membahas kajian manajemen terkait pemasaran produk-produk dengan memperkuat branding. Fokus pada kepemimpinan sumber daya manusia dalam meningkatan produktifitas. Saat ini peneliti membahas B Ikhlas Kontraktual dan Ikhlas Non Kontraktual: Kontekstualisasi Motto Ikhlas Beramal di Era Human Capital 9. (c) 2020 The Author(s). This open access article is distributed under a Creative Commons Attribution (CC-BY) 4.0 license 


\section{Pendahuluan}

Kata ikhlas merupakan terminology sacral dalam teks agama yang selalu dikaitkan dengan keyakinan dan ritual keagamaan. Kata ikhlas dalam kitab suci adalah sesuatu yang sesuatu yang mengandung nilai-nilai sakralitas, sesuatu yang murni, absolut, berasal dari ranah ketuhanan. Untuk memahami kesakralan dalam kitab suci tersebut para ulama lebih menjaga sakralitasnya dengan meminimalisir campur tangan interpretative mereka dalam pemahaman kata ikhlas tersebut dengan menyerahkannya pada tafsir kitab (yang sacral) dengan penjelasan tekstual pada kitab (yang sacral) itu sendiri dengan cara tafsir ayat bil ayat (Muharir, 2015).

Kata ikhlas ketika sudah disandangkan dengan sesuatu yang fana maka iapun berubah menjadi sesuatu yang profan. Ikhlas dalam rangkaian kata tersebut sudah menjadi hasil pemikiran agama dengan kata lain ia telah berubah menjadi berasal dari selain Tuhan [manusia], bersifat temporal, berubah, dan tidak sakral. Dalam perwujudannya, sangat wajar orang kadang mengalami kesulitan untuk membedakan diantara sakralitas dan profan dari kata ikhlas tersebut karena terjadi tumpangtindih tindih dan terjadi pencampuradukan makna antara agama dengan pemikiran agama (Muhammad, 2013). Terdapat motivasi di balik pensandangan profan dengan atribut yang sacral. Bangunan kata yang disandangkan dengan kata-kata sacral akan tertular dengan nilai-nilai sakral sehingga terpancarkan dari bangunan kata yang terbangun untuk menghasilkan makna dari simbol dan akomodasi ritual pada sistem kepercayaan yang dianut oleh masyarakat yang berada dalam lingkup kata-kata tersebut. Hasil yang diharapkan dari upaya tersebut adalah setting tatanan suatu lingkungan yang dapat mempengaruhi perilaku manusia dalam naungan kata-kata tersebut untuk berperilaku menyesuaikan dirinya dengan kata-kata tersebut (Dwindi \& Dharoko, 2018).

Motto Kementerian Agama "Ikhlas Beramal" lahir di masa perjuangan fisik kemerdekaan bangsa Indonesia. Sekian puluh tahun semenjak kehadirannya motto tersebut telah dibiarkan begitu rupa untuk tidak banyak diartikan teknis operasionalnya untuk menjaga sakralitas motto tersebut. Berbagai pemaknaan sekedarnya hadir pada buku tentang etos kerja Kementerian Agama dengan menyandarkan makna ikhlas beramal sebagai "niat ikhlas" (Inpektorat Jenderal, 2009).

Berbagai terpaan kasus korupsi yang mendera Kementerian Agama mempertanyakan kembali arti ikhlas beramal dalam motto Kementerian Agama utamanya tertuju kepada para elite Kementerian Agama (Adhi Prakosa \& Widagdo, 2013). Kasus Nilai-nilai korupsi yang sejatinya bertolak belakang dengan makna ikhlas kemudian tercitrakan menyatu dengan para elite Kementerian Agama. Hal ini mengungkap kembali teori encyclical mater et magistra dari paus John XXIII ketika kata-kata sacral digunakan oleh para elite Kementerian Agama yang "menyadari kewajiban - kewajiban mereka", mengusahakan kemajuan bagi rakyat, sehingga rakyat, sebagai rasa terima kasihnya menerima mutlak doktrin kaum elite serta menyesuaikan perilakuya terhadap doktrin tersebut (Kishor, 1998). Doktrin "ikhlas" yang sacral dan motto ikhlas beramal yang dengan sengaja disakralkan dengan senyatanya justru menjadi senjata kaum elite Kementerian Agama untuk menjinakkan tuntutan keadilan terhadap pengabdian "rakyat" Kementerian Agama sedangkan elite terlepas dari tuntutan perilaku motto tersebut (Syukri, 2020).

Mempertimbangkan hal di atas alih-alih mengganti motto Kementerian Agama yang historis, lebih diperlukan kontekstualisasi teks sacral motto "Ikhlas Beramal" yang lebih berkeadilan terhadap "rakyat" Kementerian Agama dengan pendekatan teori yang berkembang di era human capital saat ini. Riset tentang organizational citizenship behavior dan doktrin Islam. Beberapa riset diantaranya Murtaza dkk, Elamin \& Tlaiss, Khaled, Jafari \& Bidarian, dan Diana. Murtaza meneliti 
tentang dampak etika kerja dalam Islam terhadap organizational citizenship behavior dengan hasil etika kerja dalam Islam memiliki dampak terhadap organizational citizenship behavior. Elamin \& Tlaiss Jafari \& Bidarian melakukan riset hubungan antara keadilan organisasi dalam nuansa Islam dengan organizational citizenship behavior menggunakan pendekatan kuantitatif dengan statistic inferensial dengan hasil terdapat hubungan positif yang signifikan antara keduanya. Khaled mengidentifikasi efek etika kerja Islam terhadap organizational citizenship behavior (Murtaza et al., 2016), (Elamin \& Tlaiss, 2015) (Khaled, 2012) (Jafari \& Bidarian, 2012). Riset Diana menemukan bahwa organizational citizenship behavior sangat sesuai dengan ajaran agama Islam yang mengajarkan perilaku ikhlas serta perilaku islami lain dalam indikatornya (Diana, 2012).

Perbedaan yang menjadi state the art dari riset ini dibandingkan riset lainnya terutama dengan riset Diana adalah riset ini berusaha untuk mengeksplorasi nilai-nilai organizational citizenship bahavior dan employee engagement mana saja yang bersesuaian dengan nilai-nilai ikhlas dari sudut kinerja pegawai dan hubungannya dengan organisasi. Tujuan riset ini adalah mengidentifikasi nilai-nilai organizational citizenship behavior dan employee engagement mana saja yang yang bersesuaian dengan makna ikhlas beramal. Riset ini memetakan unsur-unsur organizational citizenship behavior dan employee engagement untuk kemudian menghubungkannya dengan nilai-nilai keikhlasan.

\section{Metode Penelitian}

Penelitian ini menggunakan pendekatan kualitatif. Metode kualitatif ini dinamakan juga sebagai postpositifistik karena berlandaskan pada filsafat postpositivisme. Metode ini juga dikenal lebih bersifat interpretive karen alebih berkenaan dengan interpretasi terhadap data yang ditemukan. Metode ini cocok untuk mengkonstruksi suatu tema penelitian di antara data-data yang berserakan untuk menjadi satu bangunan suatu tema lain yang lebih bermakna dan mudah dipahami. Teknik yang dipakai adalah teknik literature study, pengumpulan data dilakukan melalui Teknik stock taking dengan cara mengumpulkan dan mengklasifikasi berbagai textbook dan jurnal serta berbagai penelitian terdahulu yang relevan (Sugiyono, 2017).

\section{Hasil dan Pembahasan}

Organizational citizenship behavior (OCB) pertama kali disampaikan oleh by Kan \& Katz pada tahun 1987 yang menyatakannya sebagai perilaku extra role yaitu perilaku baik yang menguntungkan kinerja organisasi namun berada di luar peran yang disepakati (Jafari \& Bidarian, 2012). Namun demikian yang melakukan penyelidikan lebih dalam tentang extra role behavior ini adalah Organ di tahun 1987 sehingga dia lebih dikenal orang sebagai pencetus OCB. Organ mendefinisikan OCB sebagai individual behavior that is not explicitly or indirectly recognized by the formal reward system and that behavior play a vital role in the effective functioning of the organization (Organ, 1988). Pada jurnal lainnya Dalal dkk menyatakan bahwa OCB adalah perilaku prosocial dengan mendefinisikannya sebagai perilaku yang berkontribusi terhadap tujuan organisasi dengan memberikan kontribusi pada lingkungan sosial dan psikologis (Dalal, Alaybek, \& Lievens, 2020).

Organ melekatkan pengertian OCB dengan syndrome prajurit tua karena seorang prajurit tua/veteran perang sangat terikat dengan semangat korps yang terbangun saat mereka menjalani perang dan semangat ini terbawa saat mereka menjalani kehidupan sipil. Semangat korps yang 
sangat menonjol dari seorang prajurit di medan perang adalah setiap prajurit pada dasarnya memiliki spesifikasi keahlian berikut tugas dan tanggung jawabnya masing-masing. Ada yang bertanggung jawab di dapur umum, ada yang bertanggung jawab mengangkut peluru, ada yang bertanggung jawab mengantar logistic mesin perang, dan ada yang bertanggung jawab berhadapan dengan musuh. Seluruhnya sudah ditentukan deskripsi kerja/kontrak kerja, tanggung jawab dan waktu pelaksanaannya. Namun demikian ketika terjadi suatu proses yang membahayakan hidup kesatuannya dikarenakan gempuran musuh maka semua akan menyesuaikan perilakunya dengan kesempatan yang dimungkinkan untuk mewujudkan tujuan kesatuan yaitu mempertahankan kelangsungan hidup kesatuan. Seorang prajurit yang sedang ditugaskan di dapur umum sekalipun Ketika dia melihat satu kesempatan yang memungkinkan secara darurat untuk bertempur secara taktis untuk mempertahankan kesatuannya maka ia akan bergerak meninggalkan dapur umum yang lebih aman untuk membantu menyelamatkan kelangsungan kesatuannya yang terdesak. Yang terbaca adalah goal tujuan kesatuan untuk bertahan dari gempuran musuh.

Dalam skema dunia sipil, segala sudut pandang untuk mencapai tujuan kesatuan berganti menjadi kesuksesan tujuan organisasi. Penugasan dan wewenang di medan tempur tergantikan dengan kontrak kinerja. Musuh yang datang mengancam adalah competitor organisasi yang siap untuk membangkrutkan organisasi. Dalam konteks ini Organ menginginkan perilaku-perilaku yang membantu organisasi untuk mencapai tujuannya wujud pada para pegawai walaupun secara kontraktual mereka tidak terikat dalam kontrak untuk melakukan perilaku tersebut. Ini menurut Organ akan membantu mewujudkan tujuan organisasi. Persoalannya adalah perilaku untuk mewujudkan kesuksean/kinerja organisasi tidak selalu berbanding lurus dengan kinerja pegawai tersebut. Evaluasi kinerja pegawai tersebut tentu saja didasarkan dari rincian kontrak kinerja dan kualitas, kuantitas serta timeline untuk mencapainya. Perilaku yang tidak berhubungan dengan pencapaian kinerja tersebut ada kalanya membantu pencapaian kinerja pegawai dan ada kalanya justru membuang waktu produktif pegawai tersebut untuk mencapai targetnya. Contoh yang bisa disampaikan dalam hal ini adalah seorang petugas perakitan sepatu akan terambil kesempatan 10 menit waktu produktifnya untuk menghasilkan sepatu rakitan bila dia membimbing rekan baru mengoperasikan alat perakitan sepatu selama 10 menit. Berbagai riset tentang OCB menyatakan bahwa OCB berpengaruh langsung positif terhadap kinerja diantaranya adalah riset Muhdar (Muhdar, 2018) namun peneliti lain hanya menemukan pengaruh tidak langsung OCB terhadap kinerja pegawai tersebut (Basu, Pradhan, \& Tewari, 2017) dan menyarankan untuk menyelidiki keberadaan pengaruh langsung OCB terhadap pegawai yang bersangkutan.

Dari paparan tersebut dapat dikatakan bahwa OCB adalah suatu perilaku baik yang menunjang kesuksesan organisasi namun tidak termasuk dalam kontrak kerja yang tidak dapat dipastikan bahwa pengorbanan pegawai dengan melakukan perilaku tersebut akan membawa secara langsung peningkatan kinerja dirinya. Dengan kata lain OCB adalah perilaku yang secara organisasional menguntungkan tetapi secara pribadi tidak dipastikan akan menguntungkan orang yang melakukannya bahkan dapat menurunkan kinerja individunya. Hal yang paling menonjol dalam OCB adalah: 1) perilaku individu di luar kontrak kinerja, 2) secara langsung meningkatkan kinerja organisas, 3) tidak dipastikan menguntungkan pelakunya.

\subsection{Employee Engagement}

Perrin's Global work study menyatakan employee engagement sebagai kesiapan pekerja dengan keterampilan yang mereka miliki dalam rangka menunjang kesuksesan organisasi mereka 
dengan bersikap fleksibel dalam berbagai situasi. Shuck dan Wollard juga mendefinisikan keterlibatan karyawan sebagai kondisi kerja yang berkembang di mana persepsi, perasaan dan perilaku karyawan ditujukan untuk mewujudkan tujuan organisasi. Definisi lainnya datang dari Maslach dkk yang memandang employee engagement sebagai kondisi di mana pegawai terikat secara energik dengan aktivitas pribadinya untuk keberhasilan professional (Bin Shmailan, 2016).

Berbagai definisi di atas menyatakan hal kunci tentang employee engagement sebagai sikap seorang pegawai. Perrin menyebutnya sebagai kesiapan pegawai dengan ketrampilan yang mereka miliki. Shuck dan Wollard mengungkapkan dalam Bahasa keterlibatan persepsi, perasaan, dan perilaku. Maslach menyatakannya dalam keerlibatan dengan aktivitas pribadinya secara professional. Paparan tersebut kecuali Shuck and Wollard (yang mengeksplisitkan perilaku) menggariskan bahwa employee engagement adalah sikap persepsi keterlibatan aktivitas pribadi. Hal ini sejalan dengan pernyataan professional yang termaknai bahwa sikap tersebut berada dalam keterampilan perilaku yang memang menjadi peran pelakunya dalam tugas kerja yang diperjanjikan.

Perbedaan antara pegawai yang terikat dengan yang tidak terikat adalah pada keterikatan secara pribadi sehingga menghasilkan kinerja professional. Dalam kondisi yang berubah sekalipun mengutip Perrin di atas pegawai tersebut fleksibel dalam berbagai situasi. Maknanya adalah pegawai yang terengaged secara sikap pribadi terikat dengan tugas profesionalnya namun keterikatan tersebut sulit dilepas sehingga terjadilah inspirasi untuk mempertajam kinerja professional tersebut dan ini merupakan kata pembedanya. Dalam Bahasa Tahir Keterikatan karyawan meliputi keterikatan kognisi, emosional, dan perilaku secara parsial dan simultan berkontribusi positif dan bermakna dalam meningkatkan kinerja perusahaan berbasis total performance scorecard (Tahir, 2013). Anitha menemukan dalam risetnya bahwa employee engagement berdampak langsung terhadap kinerja pegawai (Anitha, 2014). Dalam kaitan ini terdapat beberapa hal penting dalam employee engagement yang akan dikaitkan dengan pembahasan nilai-nilai ikhlas. Employee engagement adalah: 1) sikap pegawai, 2) melibatkan pekerjaannya secara pribadi, 3) Tangguh dalam penyelesaian tugas tersebut, 4) berdampak langsung/meningkatkan kinerjanya

\subsection{Ikhlas}

Ikhlas secara bahasa diartikan Qalami dalam Chizanah dan Hadjam sebagai bersih,suci, sedangkan dalam terminologinya ikhlas dartikan sebagai niat yang murni semata-mata mengharapkan penerimaan dari Tuhan dalam melakukan suatu perbuatan, tanpa menyekutukan Tuhan dengan yang lain (Chizanah \& Hadjam, 2013). Ikhlas dalam konteks motto Kementerian Agama "ikhlas beramal" diartikan sebagai kesanggupan Departemen Agama untuk "melayani masyarakat dengan prima (execellence) tanpa pamrih yang menunjukkan "profesionalisme" aparatur Departemen Agama dalam menjalankan tugas sesuai dengan karateristik Departemen Agama itu sendiri (Inspektorat Jenderal, 2009).

Lebih dari pada itu dinyatakan bahwa nilai dasar (ikhlas beramal) tersebut perlu direvitalisasi, di mana pemahaman beramal merupakan bentuk produktivitas kerja yang harus dilakukan dari niat yang ikhlas dalam rangka mengabdikan diri kepada bangsa dan negara sekaligus bagian dari ibadah kepada Allah SWT sebagai pelayan bagi masyarakat (Khadimul Ummah). Menurut Farid dalam Diana, seorang pekerja yang ikhlas tidak membatasi kuantitas dan kualitas pekerjaannya sebatas nilai gaji yang diterima. Pekerja ikhlas sering kali bekerja lebih lama, lebih serius, lebih 
banyak dari karyawan lain, karena ia ingin memberi yang terbaik tanpa mengharapkan imbalan tambahan. la bahkan akan memberi nilai lebih dari yang diharapkan perusahaan. la tidak pernah bertransaksi dalam membantu rekan kerja dan bawahannya. Semua dilakukan karena ia bisa, karena ingin memaksimalkan potensi yang ada pada dirinya sebagai bentuk syukur pada Tuhan (Diana, 2012). Pekerja yang mengambil upah dari pekerjaannya tidak berarti amalnya berubah menjadi amal yang tidak ikhlas.

Yang menjadi inti dari persoalan ikhlas adalah ia merupakan amalan hati. Mujahid dalam Herman mengartikan ikhlas sebagai ketulusan hati dalam melakukan perbuatan hanyamengingatkan kepada Allah dan kehidupan akhirat (Herman, 2002). Yang menjadi kata kunci dari motto Kementerian Agama ikhlas beramal adalah: 1) perbuatan hati, 2) tidak dapat ditentukan nilai keikhlasannya dari mendapat atau tidak mendapatkan imbalan, 3) memaksimalkan potensi dirinya dalam bekerja sebagai bentuk syukur.

\subsection{Ikhlas Kontraktual dan Ikhlas Non Kontraktual}

Secara kilas, perilaku OCB seringkali langsung dihubungkan beberapa peneliti dengan ikhlas. Hal ini didukung oleh Murtaza dkk, Elamin \& Tlaiss, Khaled, Jafari \& Bidarian, dan Diana. Dalam pembahasan di atas OCB sangat cepat Nampak sebagai satu bentuk perilaku ikhlas dengan ciri-cirinya yang: 1) melakukan aktivitas di luar kontrak kinerja, 2) secara langsung meningkatkan kinerja organisas, 3) tidak dipastikan menguntungkan pelakunya. Poin nomor tiga berupa tidak dipastikan mengutungkan pelakunya tersebut dengan mudah memancing peneliti lain untuk secara cepat menghubungkan dengan ikhlas, dalam hal ini peneliti bersepakat dengan mereka.

Adapun halnya dengan employee engagement terdapat satu poin penting yang secara kilas menampakkan bahwa employee engagement bukanlah suatu sikap yang ikhlas. Poin tersebut adalah berdampak langsung/meningkatkan kinerjanya yang bila dihubungkan dengan remunerasi maka terkesan orang yang bersikap engaged dengan pekerjaannya akan tampak sebagai orang yang memiliki pamrih atas sikap profesionalnya tersebut. Berlawanan dengan hal ini beberapa pengertian ikhlas yang dipaparkan di atas justru menampakkan poin yang paling penting dari suatu keikhlasan yaitu: 1) ikhlas adalah perbuatan hati, yang 2) tidak dapat ditentukan nilai keikhlasannya dari menerima atau tidak menerima imbalan, sejauh orang tersebut 3) memaksimalkan potensi dirinya dalam bekerja sebagai wujud syukur. OCB memaksimalkan potensi dirinya dalam bekerja dengan melakukan perilaku yang secara kontraktual tidak dituntut organisasi dari dirinya sedangkan employee engagement memaksimalkan potensi dirinya dalam bekerja dengan melakukan pekerjaan yang diikat secara kontraktual oleh organisasi dengan mengerahkan seluruh potensi terbaiknya agar hasil kerjanya bukan saja memenuhi target tetapi kalau mungkin melampauinya.

OCB senyatanya secara langsung tidak terhubung dengan kinerja dan imbalan. Di sisi lain employee engagement secara langsung berdampak terhadap kinerja dan juga imbalan. Namun demikian keduanya memiliki persamaan dalam sifat keikhlasan yaitu memaksimalkan potensi dirinya dalam bekerja sebagai wujud syukur. Dalam posisi ini maka keduanya, baik OCB maupun employee engagement adalah wujud keikhlasan dalam dua bentuk yang berbeda 


\section{Simpulan}

Ikhlas beramal memerlukan revitalisasi dalam konteks era human capital. Kontekstualisasi tersebut tidak akan menurunkan derajat kesakralan motto Kementerian Agama tersebut namun justru akan meningkatkan trust sekaligus menjadi representasi affirmative action bagi "rakyat" Kementerian Agama setelah sekian lama menjadi objek penderita para elite. Salah satu revitalisasi motto ikhlas beramal yang diidentifikasi mewakili adalah organizational citizenship behavior yang dapat menjadi indicator ikhlas non kontraktual dan employee engagement yang dapat menjadi indicator ikhlas kontraktual.

\section{Referensi}

Adhi Prakosa, M. D., \& Widagdo, M. B. (2013). Hubungan Terpaan Pemberitaan Kasus Dugaan Korupsi Pengadaan Al Quran Pada Kementerian Agama Di Media Massa Dengan Citra Kementerian Agama Di Masyarakat. Interaksi Online; Vol 2, No 2: April 2013, 2(2). Retrieved from https://ejournal3.undip.ac.id/index.php/interaksi-online/article/view/2408

Anitha, J. (2014). Determinants of employee engagement and their impact on employee performance. International Journal of Productivity and Performance Management, 63(3), 308-323. https://doi.org/10.1108/JJPPM-01-2013-0008

Basu, E., Pradhan, R. K., \& Tewari, H. R. (2017). Impact of organizational citizenship behavior on job performance in Indian healthcare industries: The mediating role of social capital. International Journal of Productivity and Performance Management, 66(6), 780-796. https://doi.org/10.1108/JJPPM-022016-0048

Bin Shmailan, A. S. (2016). The relationship between job satisfaction, job performance and employee engagement : An explorative study. Issues in Business Management and Economics, 4(January), 18. https://doi.org/http://dx.doi.org/10.15739//BME.16.001

Chizanah, L., \& Hadjam, M. N. R. (2013). Penyusunan Instrumen Pengukuran ikhlas. Psikologika, 18(1), $39-49$.

Dalal, R. S., Alaybek, B., \& Lievens, F. (2020). Within-Person Job Performance Variability over Short Timeframes: Theory, Empirical Research, and Practice. Annual Review of Organizational Psychology and Organizational Behavior, 7, 421-449. https://doi.org/10.1146/annurev-orgpsych-012119-045350

Diana, I. N. (2012). Organizational Citizenship Behavior (OCB) Dalam Islam. Jurnal IImu Ekonomi Dan Sosial, 1(2), 141-148. https://doi.org/10.1074/jbc.273.13.7547

Dwindi, R., \& Dharoko, A. (2018). Ruang Sakral Dan Profan Dalam Arsitektur Masjid Agung Demak, Jawa Tengah. Inersia, 14(1), 13-25. https://doi.org/10.21831/inersia.v14i1.19491

Elamin, A. M., \& Tlaiss, H. A. (2015). Exploring the relationship between organizational citizenship behavior and organizational justice in the Islamic Saudi Arabian context. Employee Relations, 37(1), 2-29. https://doi.org/10.1108/ER-03-2014-0033

Herman, H. (2002). Kinerja Pendidik Ditinjau Dari Dimensi Ikhlas Beramal. At-Ta'dib, IX(2), 197-211.

Inpektorat Jenderal, K. A. (2009). Silabus Modul I Pengawasan Dengan Pendekatan Agama (1st ed.). 
Jakarta: Inspektorat Jenderal Kementerian Agama.

Inspektorat Jenderal, D. A. R. (2009). Pengembangan Budaya Kerja Departemen Agama (1st ed.). Jakarta: Inspektorat Jenderal Kementerian Agama.

Jafari, P., \& Bidarian, S. (2012). The Relationship Between Organizational Justice and Organizational Citizenship Behavior. Procedia - Social and Behavioral Sciences, 47(2012), 1815-1820. https://doi.org/10.1016/j.sbspro.2012.06.905

Khaled, M. K. A. (2012). The role of Islamic work ethics in developing organizational citizenship behavior at the Jordanian Press Foundations. Journal of Islamic Marketing, 3(2), 139-154. https://doi.org/10.1108/17590831211232555

Kishor, T. (1998). Justice and international development from Mater et Magistra to Centesimus Annus. International Journal of Social Economics, 25(11/12), 1739-1754. https://doi.org/10.1108/03068299810233402.

Muhammad, N. (2013). Memahami Konsep Sakral Dan Profan Dalam Agama-Agama. Jurnal Substantia, 15(2), 268-280. Retrieved from http://ejournal.kopertais4.or.id/sasambo/index.php/alirfani/article/view/2876

Muharir, M. (2015). Ragam Tafsir: Dari Bil Matsur ke Hermeneutika. Al-IIfani, 3(1), 30-52. Retrieved from http://ejournal.kopertais4.or.id/sasambo/index.php/alirfani/article/view/2876

Muhdar, H. (2018). The Effects of Spiritual Intelligence and Organizational Citizenship Behavior to Employees Performance: Study at Sharia Banks in Gorontalo Province. Economica: Jurnal Ekonomi Islam, 9(2). https://doi.org/10.21580/economica.2018.9.2.2806

Murtaza, G., Abbas, M., Raja, U., Roques, O., Khalid, A., \& Mushtaq, R. (2016). Impact of Islamic Work Ethics on Organizational Citizenship Behaviors and Knowledge-Sharing Behaviors. Journal of Business Ethics, 133(2), 325-333. https://doi.org/10.1007/s10551-014-2396-0

Organ, D. W. (1988). Organizational citizenship behavior: The good soldier syndrome (1st ed.). Lexington: Lexington Books. Retrieved from https://psycnet.apa.org/record/1988-97376-000

Sugiyono. (2017). Metode Penelitian Kombinasi (Mixed Methods). In Alfabeta (Cet 9). Bandung: Alfabeta.

Syukri, S. (Kankemenag O. Wawancara. , (2020).

Tahir, R. (2013). Keterikatan Karyawan Dan Kontribusinya Dalam Meningkatkan Kinerja Perusahaan. Jurnal IImu Manajemen \& Bisnis, 04(01), 51-60. https://doi.org/https://doi.org/10.17509/jimb.v4i1.988 